\title{
$\mathrm{Al}-\mathrm{Mg}-\mathrm{Si}$ 合金のクリープ特性に及ぼす時効の影響
}

\author{
安藤 誠 $* * *$. 新倉 昭男 $* * *$. 鈴木 義和 $* * *$. 伊藤 吾朗 $* * * *$
}

Journal of The Japan Institute of Light Metals, Vol. 64, No. 6 (2014), 229-234

(C) 2014 The Japan Institute of Light Metals

\section{Effects of aging conditions on creep behavior of an $\mathrm{Al}-\mathrm{Mg}-\mathrm{Si}$ alloy}

\author{
Makoto ANDO ${ }^{* * * *}$, Akio NIIKURA***, Yoshikazu SUZUKI*** and Goroh ITOH****
}

Creep behavior of an $\mathrm{Al}-0.3 \% \mathrm{Mg}-0.5 \% \mathrm{Si}$ alloy affected by aging condition was investigated to obtain fundamental knowledge on the thermal stability in the service temperature range for the precipitation-hardened aluminum heat-exchanger. The alloy was aged at $175^{\circ} \mathrm{C}$ for $3 \mathrm{~h}$ (under-aged; the specimen will be termed "UA specimen") and $24 \mathrm{~h}$ (peak-aged; "PA specimen"), after solution treatment. These specimens were subjected to creep testing at temperatures of $150^{\circ} \mathrm{C}$ and $200^{\circ} \mathrm{C}$. When the creep temperature was $150^{\circ} \mathrm{C}$, the UA specimen showed a lower creep rate than that of the PA specimen. On the other hand, when the creep temperature was $200^{\circ} \mathrm{C}$, both specimens showed almost the same creep rate. In accordance with the higher creep resistance, TEM images demonstrated that fine precipitates were formed in the UA specimen, but not in the PA specimen, during creep testing at $150{ }^{\circ} \mathrm{C}$. These results suggest that the higher creep resistance of the UA specimen is derived from the dynamic precipitation, probably transition from clusters to needle-shaped precipitates, during creep deformation that increases the numerical density of the precipitates because the testing temperature is lower than the aging temperature. When the creep temperature is $200^{\circ} \mathrm{C}$, higher than the aging temperature, however, the dynamic precipitation does not increase the numerical density of the precipitates, since the UA specimen as well as PA specimen is immediately over-aged at an early stage of the testing.

(Received December 19, 2013 Accepted March 21, 2014)

Keywords: creep, age hardening, heat exchanger, high temperature deformation

\section{1. 緒言}

自動車用熱交換器には，Al-Mn系合金の表層にろう材とし て Al-Si系合金をクラッドしたブレージングシートが広く用 いられており, 近年は材料薄肉化のために高強度化の要求が 高まっている。ブレージングシートの心材に $\mathrm{Mg}$ が存在する と, ろう付加熱時に溶体化され，さらにこれを時効硬化させ ることにより大幅な高強度化を達成できる ${ }^{1)}$ 。ここで時効に 関与する合金元素は Mg および $\mathrm{Si}$ であるので，心材に Mg を 添加したブレージングシートの時効挙動は, $\mathrm{Al}-\mathrm{Mg}-\mathrm{Si}$ 系合

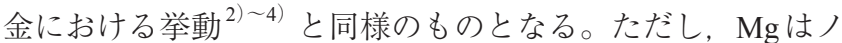
コロックブレージングにおけるろう付性を低下させるため, その添加量はおよそ $0.4 \mathrm{mass} \%$ 以下（以下では断りのない限 り組成 (mass\%) は\%と略記する) に制限されることとなる。 また，熱交換器の使用環境が高温となる場合は，長時間の負 荷によって生じるクリープ変形についても考慮する必要があ る。著者らは, $\mathrm{Al}-\mathrm{Mn}$ 系合金への $\mathrm{Mg}$ の添加は, 耐クリープ 性の向上に対しても有効であることを過去に報告した ${ }^{5)}$ 。

しかし，ブレージングシートは熱交換器の温度環境にさら
されることとなるため，その間にさらに時効が進行すること を考慮しなければならない。すなわち, 材料がクリープ変形 しながら, 同時に時効する場合の挙動についての知見が必要 である。 $\mathrm{Al}-\mathrm{Mg}-\mathrm{Si}$ 系の時効硬化を利用する場合, 最大強度 付近まで時効して用いるのが通常であるが, 熱交換器の温度 環境にさらされる間の時効も考慮した場合，製品の段階では 必ずしも最大強度にするのが適しているとは限らない可能性 が考えられる。しかし，このようなクリープ中の時効に関す る知見はそしい。 $\mathrm{Al}-\mathrm{Cu}-\mathrm{Mg}$ 系合金についての報告では，時 効条件の違いによるクリープ特性の変化に対して，運動転位 周囲の溶質元素雲囲気による影響が支配的であるとされてい $3^{6), 7)}$ 。しかし, 溶質元素濃度が比較的低く, 運動転位周囲 の雲囲気による影響が小さい, $\mathrm{Al}-\mathrm{Mg}-\mathrm{Si}$ 系合金についての 報告は見当たらないのが現状である。

そこで本研究においては， $\mathrm{Al}-0.5 \% \mathrm{Si}-0.3 \% \mathrm{Mg}$ 合金を供試 材として用い，時効とクリープ挙動との関係について検討 した。なお，本研究では時効挙動を検討しやすくするため， Mnを含有しない合金を供試材とした。

*株式会社UACJ（７366-8511＼cjkstart埼玉県深谷市上野台 1351）。UACJ Corp. (1351 Uwanodai, Fukaya-shi, Saitama 366-8511).

E-mail: ando-m@uacj.co.jp

**茨城大学理工学研究科物質科学専攻大学院生（日立市）。Graduate Student, School of Science and Engineering, Ibaraki University (Hitachi-shi, Ibaraki).

****株式会社UACJ (深谷市)。UACJ Corp. (Fukaya-shi, Saitama).

****茨城大学工学部機械工学科（日立市）。Department of Mechanical Engineering, Ibaraki University (Hitachi-shi, Ibaraki). 


\section{2. 実験方法}

99.9\%のアルミニウム地金を用いて Table 1 に示す化学組 成の合金を調整し，DC鋳造により厚さ $80 \mathrm{~mm}$ ，幅 $200 \mathrm{~mm}$ の 鋳塊とした。この鋳塊に熱間圧延および冷間圧延を施し，厚 さ $1 \mathrm{~mm}$ の板材とした。この板材から, 圧延方向を引張方向 としたJIS5 号引張試験片およびッバ付きクリープ試験片を 切出した。

これらの各試験片に対し, 塩浴炉にて $600^{\circ} \mathrm{C} て ゙ 3 \min$ の溶 体化処理，室温の水に焼入れ後， $175^{\circ} \mathrm{C}$ の大気炉にて等温時 効処理を施し，その後室温引張試験，高温引張試験およびク リープ試験に供した。室温および高温引張試験においては, $175^{\circ} \mathrm{C}$ の時効処理時間は $3 \sim 168 \mathrm{~h}$ とし, この結果からクリー プ試験前の $175^{\circ} \mathrm{C}$ 時効処理時間として, $3 \mathrm{~h}$ および $24 \mathrm{~h}$ を選択 した。溶体化以降の熱処理，試験の流れを Fig. 1 に示す。

室温および高温引張試験における初期ひずみ速度は $3 \times$ $10^{-3} / \mathrm{s}$ とした。高温引張試験における加熱には恒温槽を用い, 恒温槽内を所定の試験温度としてから試験片をセットし, 試 験片が試験温度より $2^{\circ} \mathrm{C}$ 低い温度に到達してから 15 分間保 持した後，試験を開始した。クリープ試験においては2 連式 のクリープ試験機を用い，室温の恒温槽内に試験片をセッ トし, 試験片が試験温度より $2^{\circ} \mathrm{C}$ 低い温度に到達してから 40 分間保持した後，試験を開始した。なお，時効処理の開始お よび水焼入れ直後 (時効 $0 \mathrm{~h}$ ) の引張試験は，水焼入れ後 5 分 以内に行った。

クリープ変形に伴う析出組織変化を捉えるために, STEM（走査透過型電子顕微鏡）観察を行った。試験片には, $175^{\circ} \mathrm{C}$ で静的に所定時間時効した後, さらに静的に $150^{\circ} \mathrm{C}$ お

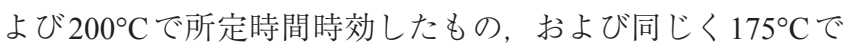
の時効後, $150^{\circ} \mathrm{C}$ おび $200^{\circ} \mathrm{C} て ゙$ 所定時間クリープ試験に供 したものを用いた。これら試験片を FIB（集束イオンビーム 装置）により薄膜化し，加速電圧 $200 \mathrm{kV}$ にて観察を行った。 薄膜化するときの膜厚は $0.1 \mu \mathrm{m}$ を狙い, 実績として $0.15 \mu \mathrm{m}$ 程度の膜厚が得られた。

また，上記STEM用に用いたものと同様の処理を施した試 験片にて, 導電率測定を行った。測定にはシグマテスタを用 い, $25^{\circ} \mathrm{C}$ の室温にて測定した。

Table 1 Chemical composition in mass\% of the alloy specimen used in this study.

\begin{tabular}{c|c|c|c}
\hline \hline $\mathrm{Si}$ & $\mathrm{Mg}$ & $\mathrm{Fe}$ & $\mathrm{Al}$ \\
\hline 0.51 & 0.30 & 0.11 & $\mathrm{Bal}$. \\
\hline
\end{tabular}

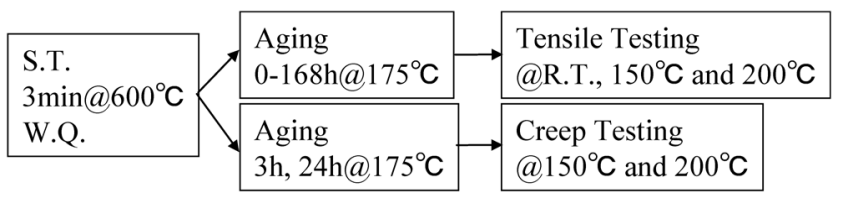

Fig. 1 Flow chart of the solution treatment (S.T.), aging and testing.

\section{3. 実験 結果}

Fig. 2 は, 室温, $150^{\circ} \mathrm{C}$ おび $200^{\circ} \mathrm{C}$ における引張試験で得 られた $0.2 \%$ 耐力 $\left(\sigma_{0.2}\right)$ および引張強さ $\left(\sigma_{\mathrm{UTS}}\right)$ と, $175^{\circ} \mathrm{C}$ での時効時間との関係を示した時効硬化曲線である。いずれ の温度での試験においても，24hの時効で最大強度が得られ ていることがわかる。この結果をもとに, クリープ試験に 供する試験材の時効時間として, 最大強度に達する前の $3 \mathrm{~h}$, および最大強度となる $24 \mathrm{~h}$ を選定した。以降, クリープ試 験前に施す時効処理として, $175^{\circ} \mathrm{C}, 3 \mathrm{~h}$ であるものを UA 材, $175^{\circ} \mathrm{C}, 24 \mathrm{~h}$ であるものをPA材と称する。

Fig. 3 は, 温度 $150^{\circ} \mathrm{C}$, 負荷応力 $110 \mathrm{MPa}$ のリープ試験 にて得られたクリープ曲線と, ひずみ速度の経時変化であ る*1。まず試験初期の挙動に着目すると, UA材は, PA材よ りも数時間程度の初期における変形が大きく, その後急激 にひずみ速度が低下する挙動を示している。ここでFig. 2の 時効硬化曲線を見ると, $\mathrm{UA}$ 材の $150^{\circ} \mathrm{C}$ における $0.2 \%$ 耐力は $105 \mathrm{MPa}$ と負荷応力ょり小さい。つまり, 初期に大きく塑性 変形し, 負荷応力と同等程度の強度まで加工硬化した段階 で急激にひずみ速度が低下したと考えられる。さらに，UA 材はその後も緩やかなひずみ速度の低下を示し, 試験時間 $100 \mathrm{~h}$ 付近で最小ひずみ速度が得られている。一方, PA材の $150^{\circ} \mathrm{C}$ における $0.2 \%$ 耐力は $158 \mathrm{MPa}$ と負荷応力より高いた め, 初期の塑性変形はUA材に比べて小さい。しかし, その 後のひずみ速度の低下は $175^{\circ} \mathrm{C}, 3 \mathrm{~h}$ 材より小さい。最小ひず み速度は同様に $100 \mathrm{~h}$ 付近で得られているが, その大きさは $175^{\circ} \mathrm{C}, 3 \mathrm{~h}$ 材の 2 倍程度となっている。その結果, 試験時間 $200 \mathrm{~h}$ 付近では変形量が逆転（クリープ曲線が交差）してい ることがわかる。

Fig. 4 は, 温度 $200^{\circ} \mathrm{C}$, 負荷応力 $60 \mathrm{MPa}$ のクリープ試験 にて得られたクリープ曲線と, ひずみ速度の経時変化であ

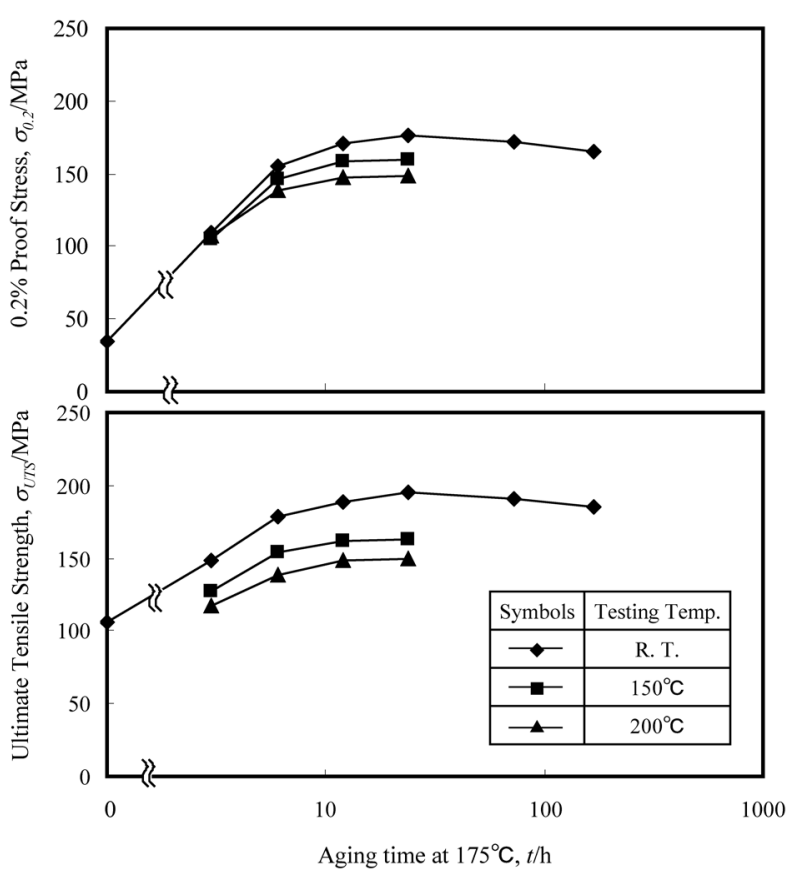

Fig. 2 Aging time vs. $0.2 \%$ proof stress; (a) and ultimate tensile strength; (b) curves of the $\mathrm{Al}-0.3 \% \mathrm{Mg}-0.5 \% \mathrm{Si}$ alloy. It is aged at $175^{\circ} \mathrm{C}$ after solution treatment. 


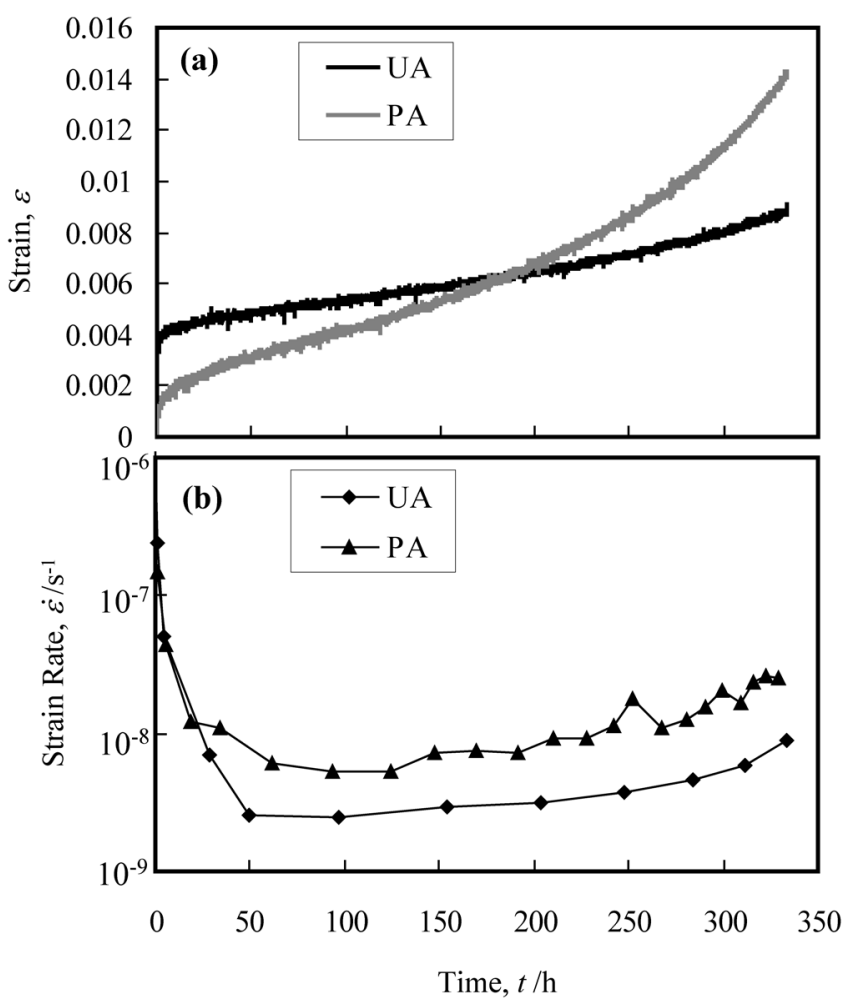

Fig. 3 Creep curves; (a) and the change of strain rate with time; (b) tested at $150^{\circ} \mathrm{C}$ under a stress of $150 \mathrm{MPa}$. The specimens are aged at $175^{\circ} \mathrm{C}$ for $3 \mathrm{~h}$ and $24 \mathrm{~h}$ (termed "UA" and "PA", respectively) before creep testing.

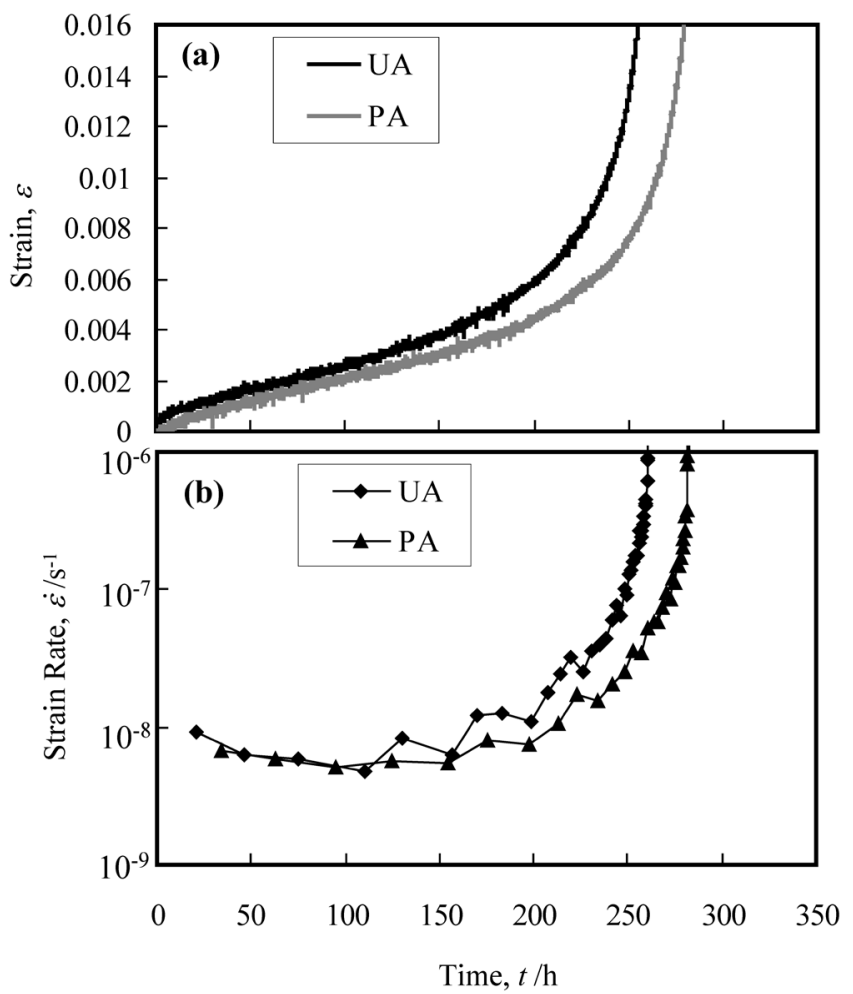

Fig. 4 Creep curves; (a) and the change in strain rate with time; (b) tested at $200^{\circ} \mathrm{C}$ under a stress of $60 \mathrm{MPa}$.

る*1。試験初期から定常クリープ領域にわたってはUA材と PA材とでクリープ挙動にほとんど違いが見られない。試験 開始から破断に至るまでの時間には若干の違いが見られるも
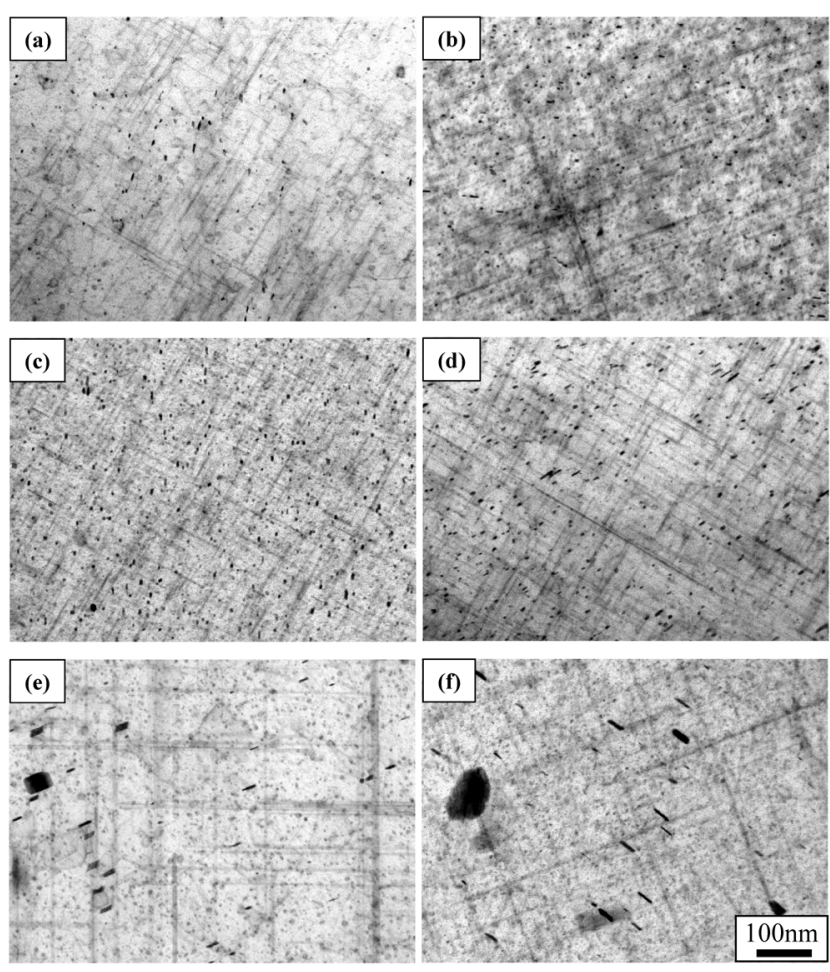

Fig. 5 Transmission electron micrographs of the specimens before creep testing; (a), (b), crept at $150^{\circ} \mathrm{C}$ and $110 \mathrm{MPa}$ for $168 \mathrm{~h}$; (c), (d), crept at $200^{\circ} \mathrm{C}$ and $60 \mathrm{MPa}$ for $168 \mathrm{~h}$; (e), (f). (a), (c) and (e) show "UA" specimens, (b), (d) and (f) show "PA" specimens. Beam direction is $\langle 100\rangle$.

のの，定常クリープ速度は両者で同程度である。

以上の結果から得られる知見を整理すると以下のようにな

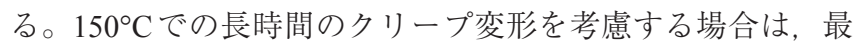
大強度を得られる時効よりも, 短時間の亜時効段階の方が耐

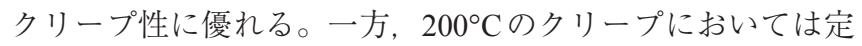
常クリープ速度という観点から考えると, 亜時効段階でも, 最大強度まで時効しても, 耐クリープ性にほとんど変化はな い。すなわち, 材料のおかれる環境が $150^{\circ} \mathrm{C}$ の場合と $200^{\circ} \mathrm{C}$ の場合とで, 事前の予備時効処理が耐クリープ性に及ぼす影 響は異なる。

このような時効条件の影響の差異は, クリープ変形中の析 出組織の変化に起因すると考えられるので，それを調べるた め, クリープ試験前, すなわち $175^{\circ} \mathrm{C} て ゙ 3 \mathrm{~h}$ および $24 \mathrm{~h}$ 時効 処理を施した後の試料と, クリープ試験中，すなわちクリー プ試験を中断した試料とを用いて，STEM観察を行った。な お，クリープ試験中断のタイミングは，いずれも定常クリー プ領域である $168 \mathrm{~h}$ (1 週間) とした。Fig. 5 に明視野像観察 した結果を示す。なお，電子線の入射方向はいずれも〈100〉 とした。試験前サンプルにおいては，PA材の方がUA材より も針状の析出物が成長しており, 観察されている析出物につ

\footnotetext{
*1Ｆig. 3(a) およびFig. 4(a)のクリープ曲線において，ひずみが瞬間 的に細かく変化する現象が見られる。これは, 運動転位が溶質原 子の雾囲気への固着, 離脱を繰返すことによって生じる, セレー ションに近い現象である可能性が考えられる。これについてはよ り詳細な検証が必要であるが, 本合金の溶質濃度は非常に希薄で あるため, ここで論じているクリープ速度に対する影響は, ごく 小さいと考えられる。
} 


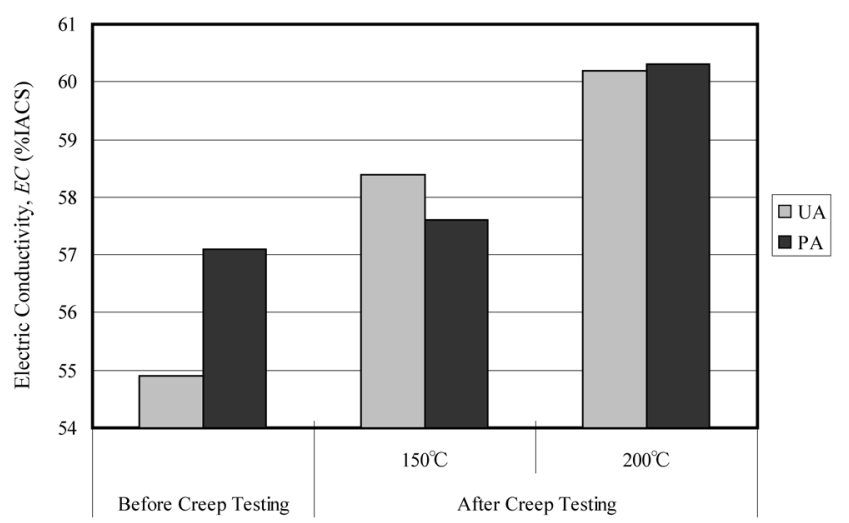

Fig. 6 Electric conductivity before and after creep testing. Each specimen are crept at $150^{\circ} \mathrm{C}$ and $110 \mathrm{MPa}$ for $168 \mathrm{~h}$, or at $200^{\circ} \mathrm{C}$ and $60 \mathrm{MPa}$ for $168 \mathrm{~h}$.

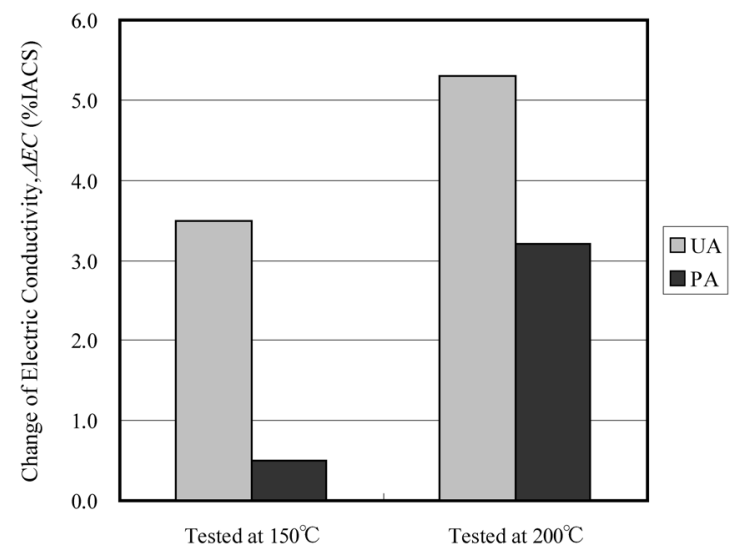

Fig. 7 Change of electric conductivity between before and after creep testing, corresponding to Fig. 6 .

いては高密度となっている*2。これは, Fig. 2 の時効曲線に おいて, $175^{\circ} \mathrm{C}, 3 \mathrm{~h}$ の時効では亜時効, $24 \mathrm{~h}$ の時効では最大強

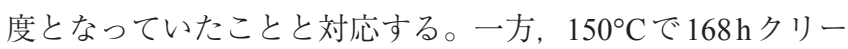
プ試験に供した後のSTEM像においては, 逆にUA材の方が

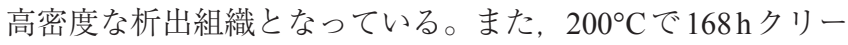
プ試験に供した後のSTEM像においては, 試験前よりも析出 組織が粗大化している様子が見られ，UA材とPA材とでほぼ 同様な組織となっている。

Fig. 5 で観察した試料について, 導電率を測定した結果 をFig. 6に示す。クリープ試験前はPA材のほうが, UA 材 よりも導電率がかなり高く, 析出量が多いことを示してお り, 時効曲線や析出組織観察と対応している。しかしクリー

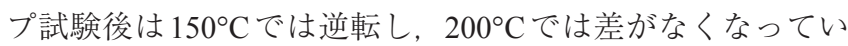
る。Fig. 7 は, Fig. 6の測定結果から, クリープ試験前後の導 電率の変化を計算したものである。これによると, $150^{\circ} \mathrm{C}$, $200^{\circ} \mathrm{C}$ ずれのクリープ試験においても, クリープ試験によ る導電率増加は, UA材の方が大きいことがわかる。これは, UA材の方がクリープ試験中における析出量が多いことを示 す。

\footnotetext{
*2 観察面に平行な析出物のコントラストは回折条件の関係で大き く変化するので比較しにくいが, 垂直な析出物で比較すれば, 高 密度化が明らかである。
}

以上の結果から, $150^{\circ} \mathrm{C}$ のリープ試験中に生じている析 出組織の変化は以下のように考えられる。UA材は亜時効段 階であるため, 最大強度を与える針状析出物は成長途中の段 階にあると考えられる。そのまま $175^{\circ} \mathrm{C} て ゙$ 時効して最大強度 まで達したPA材の場合, そのような組織の一部は消失して しまう。しかし亜時効段階で $150^{\circ} \mathrm{C}$ のクリープ試験に供した UA 材の場合, その温度が時効温度より低いため, 消失せず に成長できる析出物が多くなると考えられる。以上のような クリープ中の析出挙動の違いにより, UA材はPA材よりも析 出物が微細に分布するため, クリープ試験中に析出物の密度 が逆転し, より微細な組織となったUA材の方がクリープ速 度が遅く，より優れた耐クリープ性を示したと考えられる。

一方, 時効温度が $200^{\circ} \mathrm{C}$ の場合には， 5 時間程度の時効で 析出物は棒状中間層に遷移し, 過時効化が進行することが知 られている ${ }^{8)}$ 。したがって, クリープ試験温度が $200^{\circ} \mathrm{C} の$ 場 合は, 時効温度よりも試験温度の方が高いため, UA 材, PA 材のどちらにおいても, クリープ試験中にはもっぱら析出 物の粗大化が進む。そのため, UA 材, PA 材ともに粗大な過 時効組織となり, 耐クリープ性も同程度となったと考えられ る。

\section{4. 考察}

以上で述べたようなクリープ変形中における材料の機械的 特性の変化について, より詳細に考察する。ここで, クリー プは静的ではなく, 変形を伴いながら時効析出が進行する現 象であるため，変形による影響についても考慮する必要があ る。

変形により導入される加工組織が時効に及ぼす影響に関連 して, 溶体化処理後に冷間加工を行った場合の時効析出に関

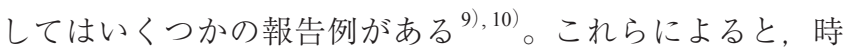
効硬化曲線はより短時間側に変化し，また熱分析において針 状析出物の析出がより低温で生じるようになることが示され ている。すなわち, 加工によって転位が導入されると, その 転位を核生成サイトとすることにより，時効析出が促進され ると考えられている。

クリープ変形中の組織変化を考える場合には，このような 加工組織と時効析出との相互作用が生じることを考慮しなけ ればならない。しかし, $\mathrm{Al}-\mathrm{Mg}-\mathrm{Si}$ 系合金の動的析出につい ては，熱間加工の温度域における報告は多く見られるもの の, 本研究で対象としているような $150 \sim 200^{\circ} \mathrm{C}$ 程度におけ る検討例は少ない。温度 $430 \mathrm{~K}\left(157^{\circ} \mathrm{C}\right)$, ひずみ速度 $10^{-3} \sim$ $10^{-2} / \mathrm{s}$ 程度における, 変形中に生じる析出の影響に関する報 告は見られるが11)，クリープのようなひずみ速度の小さな 変形における挙動は明らかでない。

そこで，変形の影響も含めたクリープ中の機械的特性の変 化を検証するため, 応力を負荷する場合としない場合との導 電率および強度の変化を調べた。前者はすなわちクリープ試 験（以下, 対比のため動的時効処理と呼ぶ）そのものであり,

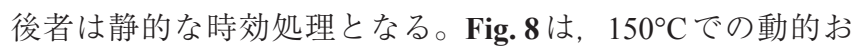
よび静的時効処理に伴う, 導電率および $0.2 \%$ 耐力 (YS) の 変化である。負荷応力は, これまでと同様に $110 \mathrm{MPa}$ とした。 まず動的時効におけるUA材と PA材との挙動を比較すると, $\mathrm{UA}$ 材のほうが等温保持前の導電率およびYSは小さいが, $10 \sim 100 \mathrm{~h}$ 程度の $150^{\circ} \mathrm{C}$ 時効により, その大小関係は逆転して 


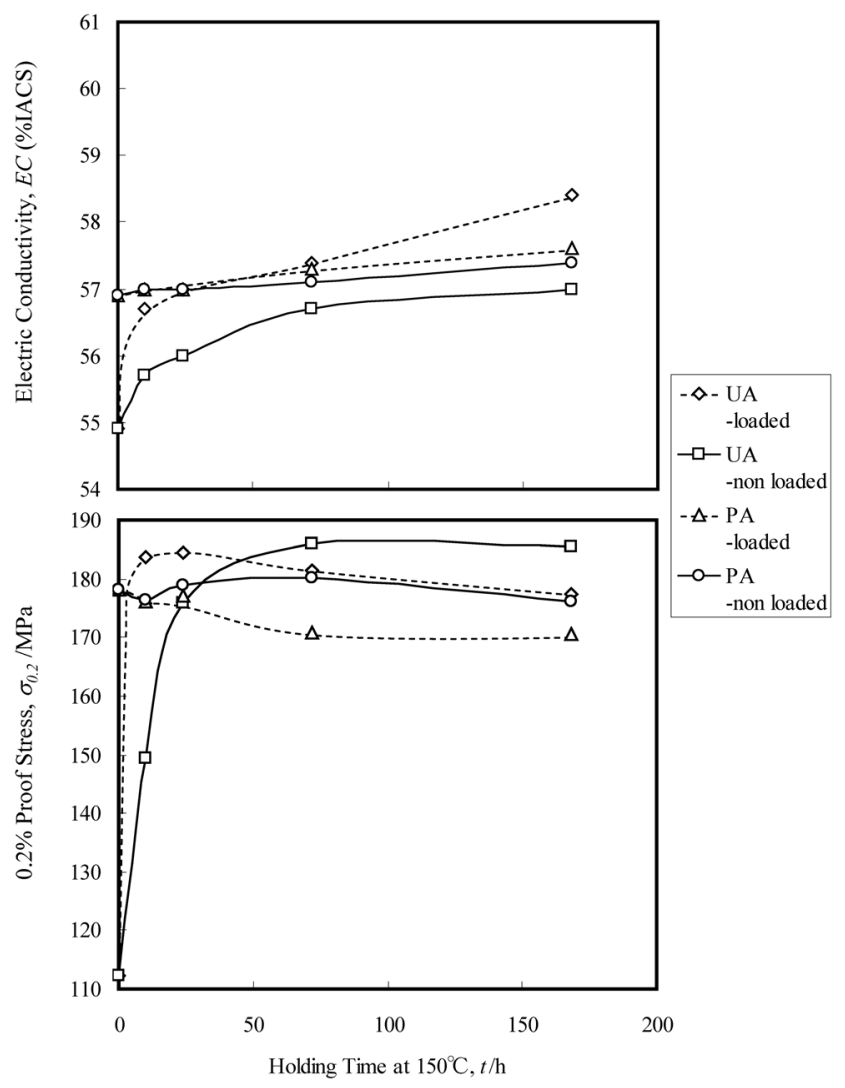

Fig. 8 Change of electric conductivity; (a) and $0.2 \%$ proof stress; (b). The loaded or non loaded specimens are held at the temperature of $150^{\circ} \mathrm{C}$, and the loaded stress is $110 \mathrm{MPa}$.

いる。すなわち，すでに述べたような，UA材は試験中にお ける新たな針状析出物への遷移が起こって析出物が高密度と なり，クリープ中に高強度化するということを裏づけるもの といえる。また，UA材について応力負荷した場合としない 場合との導電率変化を比較すると，応力負荷した場合の方が 大きく変化しており， $150^{\circ} \mathrm{C}$ で $168 \mathrm{~h}$ 保持した後の導電率は 応力負荷した場合の方が高くなっている。また，YSについ て同様の比較をすると, $150^{\circ} \mathrm{C}$ 保持 24 時間までは, 応力負荷 した場合の方が高い強度を示している。これらの結果は, 応 力負荷して材料が変形することによって $150^{\circ} \mathrm{C}$ 等温保持中の 析出が促進され，静的に等温保持した場合よりも早期に高密 度な時効析出物が生成し，高い強度が得られていることを示 すものであると考えられる。しかし，等温保持時間 $72 \mathrm{~h}$ 以降 においては，応力負荷した場合のYSが大きく低下し，応力 負荷しない場合よりも低くなっている。以上のことから，ク リープ変形による影響として，UA材においては，クリープ 試験初期にはクリープ変形により時効硬化が促進され，変形 が抑制される効果が現れていると考えられるが，同時に過時 効化も促進されるため，ピーク強度を過ぎた後の強度低下を 促進する影響も及ぼすと考えられる。一方で，PA材につい ては, クリープ試験初期のYSは応力負荷した場合としない 場合とでほとんど変わらず，等温保持時間 $72 \mathrm{~h}$ 以降において は，応力負荷した場合のYSが大きく低下し，応力負荷しな い場合よりも低くなっている。すなわち，クリープ試験前に 材料を最高強度まで時効した場合は, クリープ変形による初 期の変形抑制の効果はほとんど現れず，過時効化を早めるこ

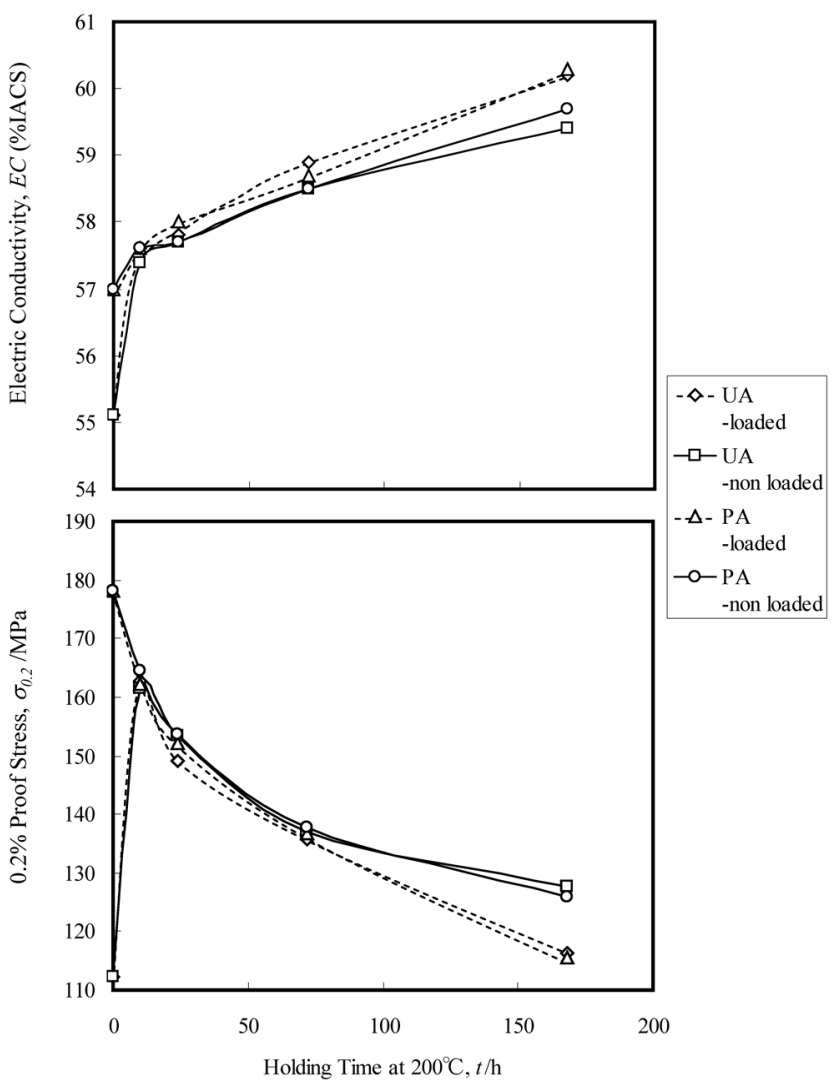

Fig. 9 Change of electric conductivity; (a) and $0.2 \%$ proof stress; (b). The loaded or non loaded specimens are held at the temperature of $200^{\circ} \mathrm{C}$, and the loaded stress is $60 \mathrm{MPa}$.

とによる強度低下の影響のみが顕著に現れると考えられる。

Fig. 9 は, $200^{\circ} \mathrm{C}$ での等温保持について, Fig. 8 と同様に導 電率およびYS を測定した結果である。負荷応力は，これま でと同様に $60 \mathrm{MPa}$ とした。まず応力負荷有りの場合におけ るUA材と PA材との挙動を比較すると, 導電率, YS のいず れにおいても， $10 \mathrm{~h}$ の $200^{\circ} \mathrm{C}$ 等温保持ですでに両者の差異は ほとんどなくなり, 以降ほぼ同じ值を示しながら変化してい ることがわかる。これは，定常クリープ領域ではほぼ同じク リープ速度を示していた結果と一致するものであると考えら れる。また，応力負荷した場合としない場合とを比較する と, どちらの時効条件においても，導電率変化は応力負荷し た場合の方が大きく，長時間保持後のYS は応力負荷した場 合の方が小さい。すなわち, クリープ温度が $200^{\circ} \mathrm{C}$ の場合に も, $150^{\circ} \mathrm{C}$ の場合と同様に, クリープ変形によって時効組織 の過時効化が促進され, 加速クリープへの遷移を早める影響 を持つと考えられる。この過時効促進の原因については, 本 研究の範囲で実験的に解明することはできなかったが，変

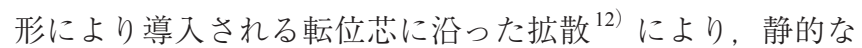
場合よりも溶質原子の拡散が速くなることによると推察され た。 $150^{\circ} \mathrm{C}$ の場合にUA材に見られた応力負荷による時効硬 化の促進においても, $150^{\circ} \mathrm{C}$ 時効により得られる最高強度值 は, 応力負荷の有無によりほとんど変化しないので, 転位が 強化に寄与する析出物の核生成サイトを提供したとは考えに くく（静的時効の場合も $150^{\circ} \mathrm{C}$ 時効中に新たな針状析出物へ の遷移が同じように起こる), やはり拡散促進の効果が主た る原因と考えられた。 


\section{5. 結言}

$\mathrm{Al}-0.3 \% \mathrm{Mg}-0.5 \% \mathrm{Si}$ 合金のクリープ特性に及ぼす, 試験前 の $175^{\circ} \mathrm{C}$ での時効処理時間の影響について検討し, 以下の知 見を得た。

（1）クリープ温度が $150^{\circ} \mathrm{C}$ の場合は, $175^{\circ} \mathrm{C} て ゙$ 最大強度と するよりも，覀時効とした方が耐クリープ性に優れていた。 亜時効の場合は, クリープ中の析出により針状析出物の密度 が高くなるためであると考えられた。

(2) クリープ温度が $200^{\circ} \mathrm{C}$ の場合は，いずれの試験前の 時効条件でも過時効化による析出物の粗大化が同様に生じる

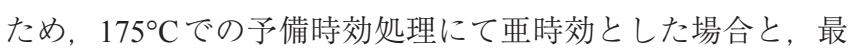
大強度とした場合とで耐クリープ性に顕著な違いは現れな かった。

（3）クリープ温度が $150^{\circ} \mathrm{C}, 200^{\circ} \mathrm{C}$ のどちらの場合におい ても, クリープ変形によって過時効化が促進されていること
が示された。

\section{参 考 文 献}

1) 葉 英華, 中島英治, 栗下弘明, 後藤正治, 吉永日出男: 日本 金属学会誌, 52 (1988), 1255-1262.

2) ASM: Metals Handbook, Vol. 2 (1998), 271.

3）馬場義雄, 高島 章：軽金属, 19（1969），90-98.

4) 鈴木 寿, 菅野幹宏, 白石泰久, 塙 健三 : 軽金属, 29 (1979), $575-581$.

5) 安藤 誠, 鈴木義和, 伊藤吾朗：軽金属, 62 (2012), 300-305.

6) R. N. Lumley, A. J. Morton and I. J. Polmear: Acta Mater., 50 (2002), 3597-3608

7) R. N. Lumley and I. J. Polmear: Scr. Mater., 50 (2004), 1227-1231.

8) G. Thomas: J. Inst. Met., 90 (1961), 57-63.

9) Z. H. Ismail: Scr. Metall. Mater., 32 (1995), 457-462.

10) J. Dutkiewicz and L. Litynska: Mater. Sci. Eng. A, 324 (2002), 239 243.

11) L. Blaz and E. Evangelista: Mater. Sci. Eng. A, 207 (1996), 195-201.

12）藤川辰一郎：軽金属, 46（1996）, 254-265. 